\title{
Possible New Sources of Power Alcohol.
}

\section{By C. Simmonds.}

$\mathrm{T}^{\mathrm{w}}$ WO reports have recently been issued dealing with various aspects of the fuel question. The first ${ }^{1}$ is devoted largely to a consideration of the supplies of alcohol which might be made available for use as a motor fuel; the second ${ }^{2}$ includes a note upon the production of alcohol from cokeoven gas, with a memorandum describing the process now being developed experimentally for the purpose. In the present article it is proposed briefly to survey the position as regards alcohol, leaving aside the question of alternative motor fuels.

As noted in the first of the two reports, the enormous and rapidly increasing consumption of liquid fuels is tending to exceed production, so that it is very important to supplement those now employed by developing the use of new ones in every possible way. In the United Kingdom the quantity of petrol received during rgi4 was about 120 million gallons; the imports in r9I9 had risen to 200 million gallons, and the estimate for the present year is 250 million gallons.

It is now accepted that alcohol, either alone or mixed with other liquids, can be used to replace petrol in internal-combustion engines, the most suitable fuel being probably a mixture of alcohol with benzol, or with benzol and ether. But to get alcohol we must first obtain the raw materials. These are, in the main, starch- or sugar-containing plants. So far as this country is concerned, grain (barley), potatoes, and mangolds would appear to be some of the most suitable crops : the last has not hitherto been used for the purpose to any large extent. Reckoning, for present purposes, a gallon of alcohol of 95 per cent. strength as equivalent to a gallon of petrol, how much of these raw materials should we require to supply the 250 million gallons which represent our annual consumption of petrol?

We should want more than 4 million tons of barley, or $12 \frac{1}{2}$ million tons of potatoes, or 25 million tons of mangolds. Roughly, the total annual production of potatoes in the United Kingdom is only one-half, and of the other two materials barely one-third, of these quantities. The barley we produce is already largely used in the making of malt; the potatoes and mangolds are foodstuffs. Since this country is very far from being self-supporting in the matter of food, no considerable proportion of these crops could be diverted to increase the production of alcohol. They command a much higher price as foodstuffs than could be paid for them as sources of "power" alcohol.

Our own case is fairly typical of the position in general. Foodstuffs, whether produced at home or abroad, will probably for some time yet

\footnotetext{
1 "Fuel for Motor Transport." An Interim Report by the Fuel Research Board, Department of Scientific and Industrial Research. (I920.)

2. "Fuel Economy." Third Report of the British Association Comnittee. (r920.)
}

No. 2660 , voL. I06] be too valuable for use on any large scale as sources of alcohol. Meanwhile, what of possible new sources?

As regards synthetic methods of making alcohol, there are only two which, so far, have come near to commercial success. One of these is the manufacture from calcium carbide, itself produced from coke and limestone. The carbide yields acetylene, which by appropriate chemical treatment is converted into acetaldehyde; and the aldehyde, when mixed with hydrogen and passed over heated nickel as catalyst, is reduced to alcohol. The process was to have been worked on a large scale in Switzerland, but little has been heard of it lately. It may have been remunerative during the war, but has not developed as much as was expected, and appears now to be hanging fire. In any case, cheap power for making the carbide is essential; and according to some German calculations it would be more profitable to convert the carbide into cyanamide, and use this as a fertiliser to increase the potato crop for conversion into alcohol. A much better yield would thus be obtained.

The other synthetic method is based upon the utilisation of a by-product. The gas emitted from coke-ovens consists mainly of hydrogen (5o per cent.) and methane (25 per cent.), with smaller quantities of nitrogen, water vapour, and tarry impurities, and about 2 per cent. of ethylene. After a preliminary purification of the crude gas to eliminate tarry matters, ammonia, naphthalene, and benzene hydrocarbons, the greater part of the ethylene can be absorbed in strong sulphuric acid, forming ethyl hydrogen sulphate, wnich, when diluted with water and distilled, yields alcohol. Experiments have shown the possibility of obtaining 1.6 gallons of alcohol per ton of coal carbonised, and according to some estimates the cost of manufacture would be about $2 s$. per gallon. Assuming a similar yield from all the coal carbonised in British coke-ovens (about ${ }_{5} 5$ million tons per annum), the yearly supply of alcohol from this source would be about 24 million gallons. The manufacture, however, is at present only in the early stages, and it is too soon to judge what the permanent prospects are. But, even if the suggested yield of 24 million gallons is eventually reached-and this, for various reasons, is unlikely-it would be less than onetenth of our present petrol consumption. It would be a very acceptable contribution, but insufficient. An increase of 100 million gallons or more should be aimed at.

Thus, for the moment at least, we are still dependent upon fermentation methods for any considerable increase in the supplies of alcohol. We come back, therefore, to the question of fermentable raw materials.

Still dealing with the needs and possibilities of 
the United Kingdom, it may be said that to produce an additional roo million gallons of alcohol we should have either to devote about 847,000 more acres to potatoes at the present average yield of $5 \frac{1}{4}$ tons per acre, or else to increase this yield to something above 9 tons on the present acreage. For the same quantity from mangolds an additional $55_{3}$, 000 acres would be required, or else a yield of $34 \frac{1}{2}$ tons per acre instead of the present average of about one-half this amount. Two suggestions have been made towards the possibility of effecting this increase. One is that by a greater use of fertilisers and better cultivation the crop yield might be raised sufficiently to meet the demand even with the present acreage, or with a relatively small increase. As regards potatoes, more than Io tons per acre have been obtained in various Irish districts, so that an average of 9 tons does not seem impossible. The figures given by the Fuel Research Board for the mangold crop in 1919 work out to $16 \frac{1}{2}$ tons per acre, but some years ago the average was 20 tons, and $24-30$ tons have been mentioned as obtainable. If the normal crop of mangolds under good conditions is anything like the last estimate, no very great increase in yield and acreage together would be required to give the raw material for Ioo million gallons of alcohol.

The second suggestion is that, leaving apart the land at present cultivated for foodstuffs, waste land might be reclaimed and devoted to carbohydrate crops for alcohol production, so that there would be no diminution of present food supplies. Again turning to Ireland, there are, according to a recent writer, thousands, and even hundreds of thousands, of acres of waste land which could, without any great expenditure of money, be utilised for the purpose. In this country some smallscale experiments on reclamation are actually in progress at Holton Heath, where several acres of heath land have been reclaimed and planted with artichokes for a practical study of the question. At present, however, the work is not sufficiently advanced to allow of useful deductions being made.

The general conclusion arrived at in the interim report of the Fuel Research Board is that the production of alcohol in any considerable quantities from vegetable materials grown in the United Kingdom is not economically possible, owing to (I) insufficient acreage; (2) high cost of cultivation, harvesting, and manufacture; and (3) the fact that the most suitable raw materials are also important foodstuffs. The two suggestions noted above might go far to meet the first and third points, but the second still remains, and it is, of course, a crucial one. In tropical and sub-tropical countries, where land is plentiful, labour cheap, and sunshine abundant, it may be quite practicable to grow vegetable substances such as cassava, arrowroot, and maize at such a cost as will make them very important sources of alcohol. Maize has been much used in the past, but just now its price-no doubt an abnormal one-precludes its

No. 2660 , VOL. IO6] use on a large scale. In regions such as South Africa and South America, however, two or even three crops can be secured yearly, and it has been urged that with proper organisation and development this raw material could, under conditions of mass-production, become one of the most important supplies.

Turning now to other possibilities, one of the first to be mentioned is the utilisation of cellulose materials as sources of alcohol. Two processes are already well known; others are in the experimental stages only. The cellulose of sawdust and other wood waste can be hydrolysed with acids and partly converted into fermentable sugars. This process has been under trial for several years in America, but has not yet definitely established itself as a successful manufacturing operation in normal times. In countries where wood pulp is made, a considerable quantity of alcohol is obtained from waste sulphite liquor, a by-product which contains a small percentage of fermentable sugars produced during the treatment of the wood. An interesting recent proposal (Rogers and Bedford) is one for obtaining alcohol from rice straw and husk, a cheap raw material available in large quantities. The straw is softened by steaming, and treated with hydrochloric acid or with calcium hypochlorite and chlorine to disintegrate the fibres, then pulped, and the hydrolysis of the cellulose and starchy matters completed by means of diluted hydrochloric acid. After the conversion to sugar is finished, the acid is neutralised, and the solution of sugars fermented and distilled. It is understood that arrangements have been made for largescale experimental trials of this process in India, with the view of ascertaining whether the production of fuel alcohol from these and similar cheap cellulose materials can be definitely established.

Experiments are also in progress to ascertain whether a micro-organism can be obtained which will effect the direct conversion of cellulose into fermentable sugar. Success on the lines of this or the preceding process would open out the prospect of utilising a large amount of waste cellulose substances as sources of alcohol.

Among other possible new sources may be mentioned a tuberous plant, Polynnia edulis, growing in the Andes, which is said to be now under trial in France. The tubers range up to $2 \mathrm{lb}$. in weight, and have a carbohydrate content comparing favourably with that of mangolds. A special sugar beet is also being experimented with. Little information, however, is available yet as to whether, in the matter of yield and cost, these plants offer any marked advantages over those now in use.

Our general survey indicates, therefore, that, although the home production may be appreciably increased, it is mainly to the organisation and development of our overseas resources that we must look for any very considerable increase in our supplies of alcohol cheap enough to be used as fuel. 